ISSN 1997-5902

\title{
Biochemical and functional properties of lactic acid bacteria isolated from Ivorian cocoa fermenting beans
}

\author{
Djéneba H. OUATTARA, *Honoré G. OUATTARA, Bernadette G. GOUALIE, Liliane M. KOUAME and \\ Sébastien L. NIAMKE \\ 1. Laboratoire de Biotechnologies, UFR Biosciences, Université Félix HOUPHOUËT-BOIGNY, 22 BP 582 Abidjan \\ (Côte d'lvoire) \\ *Corresponding author: kidou12@yahoo.fr Phone/Fax: 00 (225) 22444473
}

Original submitted in on 19th February 2014. Published online at www.m.elewa.org on $31^{\text {st }}$ May 2014. http://dx.doi.org/10.4314/jab.v77i1.9

\begin{abstract}
Objective: Fermentation is an important step in the post-harvest processing of cocoa beans. The quality of beans and chocolate depends strongly on the type and characteristics of microbial strains involved in the fermentation. This study investigates some functional properties of lactic acid bacteria (LAB), involved in Côte d'Ivoire cocoa fermentation.

Methodology and results: Bacterial growth was monitored during spontaneous heap fermentation using plate count and decimal dilution methods. LAB was present throughout the fermentative process with a load comprised between $6.0 \mathrm{log}$ (UFC/g of bean) at the beginning to $6.60 \mathrm{log}$ (UFC/g of bean) at the end. The maximum load of LAB corresponding to $7.22 \mathrm{log}$ (UFC/g of bean) was reached after $24 \mathrm{~h}$ of fermentation in the condition of $42^{\circ} \mathrm{C}$ of temperature and $\mathrm{pH}$ round 3.55 . Among the 150 strains isolated, 99 were lactobacilli and 51 lactococci. Almost all these LAB showed ability to ferment glucose, fructose and sucrose with an important acidification capacity while only 8 strains belonging to lactococci proved to be able to assimilate citrate. Moreover, a weak proportion $(7.33 \%)$ of LAB strains isolated was heterofermentative type. These heterofermentative $L A B$ strains were particularly characterized by a great fermentative capacity especially with glucose and sucrose with a gas production up to $5 \mathrm{~mL}$.

Conclusion and application of results: The citrate metabolism and the strong fermentative capacity of certain LAB strains, indicate interesting technological traits potentially useful for their utilization as starters in cocoa fermentation.
\end{abstract}

Key words: lactic acid bacteria, fermentative power, cacao fermentation, acidification, citrate metabolism.

\section{INTRODUCTION}

The processing of cocoa beans consists of two major steps namely fermentation and drying (Hii et al., 2009; Guehi et al., 2010). Fermentation as the first stage in the preparation of chocolate begins immediately after the beans embedded in mucilaginous pulp are removed from the pods. Cocoa fermentation is a key step in the technological transformation of cocoa into chocolate, because the highly bitter, astringent unfermented cocoa beans lack the full chocolate flavour. During fermentation, cocoa pulp is hydrolyzed and this aids the drying process by allowing the pulp to be drained. Most importantly, fermentation triggers an array of chemical changes 
within the cocoa bean that are vital to the development of the complex, beloved flavour of "chocolate" (Pereira et al., 2012). The fermentation of cocoa beans occurs at two levels. The first involves reactions that take place in the pulp, in the outer part of the beans, and the second involves several hydrolytic reactions that occur within the cotyledons (Lehrian and Patterson, 1983). The microbial activity in the cocoa pulp is a well-defined microbial succession in which numerous microbial species, mainly yeasts and bacteria including Bacillus, acetic acid bacteria (AAB) and lactic acid bacteria (LAB) are involved (Schwan et Wheals, 2004; Ouattara et al., 2008). At the onset of cocoa beans fermentation, yeasts liquefy the pulp through depectinization, which reduces pulp viscosity, and produce ethanol from sugars (and citric acid) under anaerobic conditions in an acid $(\mathrm{pH}<4.0)$, carbohydrate-rich environment. As pulp is drained away, ethanol formation proceeds and both temperature and $\mathrm{pH}$ increase, which creates ideal conditions for the growth of $L A B$ and $A A B$. $L A B$ converts sugars and organic acids mainly into lactic acid but others species such as heterofermentative $L A B$ product in addition acetic acid, gas $\left(\mathrm{CO}_{2}\right)$ and ethanol. As more air comes in, $A A B$ start to grow that, oxidize the ethanol, initially produced by the yeasts, to acetic acid. Ethanol and acetic acid diffuse into the beans, and this, in combination with the heat produced by this exothermic bioconversion, causes the death of the seed embryo as well as the end of fermentation. In addition, this initiates biochemical changes in the beans, leading to the formation of precursor molecules for the development of a characteristic

\section{MATERIAL AND METHODS}

Fermentation condition and sampling: Cocoa pods were harvested from Agboville (geographic coordinates $5^{\circ} 59^{\prime}$ north $4^{\circ} 28^{\prime}$ West), situated at $79 \mathrm{~km}$ from Abidjan (Côte d'Ivoire). Beans were removed from pods and fermented traditionally by heap fermentation during six days. The fermenting mass about $100 \mathrm{~kg}$, set on banana leaves and covered with banana leaves was constituted of mixed genotypes (Forastero, Trinitario and Criollo cultivars). Banana leaves are the main flavour and colour of the beans (Hansen et al., 1998, Thompson et al., 2001). Therefore, the activities of $L A B, A A B$ and yeast in this process are essential for the production of high-quality cocoa. On the other hand, fermentation is a natural microbial process, which remains difficult to control. In this context, many studies suggest the use of starter microbial culture as a best approach to improve fermentation process (Carr et al., 1980; Passos et al., 1984; Hansen et al., 1998; Hashim et al., 1998; Nielsen et al., 2005; Papalexandratou et al., 2011; Koen et al., 2012). Thus, several microbial cultures, including lactic acid bacteria have been assayed to analyze their potential as starters. These assays are mainly to analyze the effect of chosen strains, on the quality of fermented product. However, before using as potential starter, the functioning and role of this strain during cocoa bean fermentation, particularly their kinetics of growth, substrate consumption and metabolite production should be studied in more detail. Several studies concerned the identification of microflora from cocoa fermenting bean have been reported in other cocoa producing country such as Ghana, Brazil, Malaysia, Trinidad (Ardhana and Fleet, 2003; Nielsen 2006; Nielsen et al., 2007; Schwan, 1998; Jespersen et al., 2005 ). Although Côte d'Ivoire stands as the first cocoa producer in the world with up to $37 \%$ of global production, the microbial flora responsible for its cocoa fermentation is still poorly characterized and unknown. In the present study, we investigate the characteristic and functional properties of lactic acid bacteria, one of the major microfloras involved in Côte d'Ivoire cocoa fermentation.

material used for traditional cocoa fermentation in Côte d'Ivoire. Samples of fermenting cocoa bean were taken according to a fixed time schedule, notably at the start of the fermentation $(0 \mathrm{~h})$ and after 24, 48, 72, $96 \mathrm{~h}, 120$ and $144 \mathrm{~h}$ of fermentation. Each sample consisted of $50 \mathrm{~g}$ of beans that was transferred into sterile plastic bags. The $\mathrm{pH}$ and temperature were also regularly recorded directly at $15 \mathrm{~cm}$ depth on the fermenting heap, with portable $\mathrm{pH}$-meter and thermometer. 
Lactic acid bacteria isolation and numeration: The culture dependent approach was performed immediately after sampling. Therefore, $225 \mathrm{ml}$ of $0.1 \%$ (wt/v) peptone water (Oxoid, Basingstoke, United Kingdom) was added to $25 \mathrm{~g}$ of beans in a sterile Stomacher bag that was vigorously shaken for $5 \mathrm{~min}$ in a Stomacher 400 (Seward, Worthington, United Kingdom) to obtain a uniform homogenate. Samples $(1.0 \mathrm{ml})$ of the homogenate were serially diluted 10 -fold in Trypton salt buffer, from which aliquots $(0.1 \mathrm{ml})$ were plated on different selective agar media; MRS (Man Rogossa and Sharpe) agar, MSE (Mayeux, Sandine and Elliker, 1962) agar, and M17 agar (all from OXOID, Basingstoke, Hampshire, UK); to obtain the widest possible species variety of $L A B$ associated with fermenting cocoa and capable of growing on these media. Plates were incubated at $37^{\circ} \mathrm{C}$ for $48-72 \mathrm{~h}$ under anaerobic conditions to enable colony count enumeration (expressed as CFU per gram cocoa pulpbean mass), as described previously (Kostinek et al., 2008). The three medium were supplemented with 50 $\mu \mathrm{g} / \mathrm{mL}$ of nystatin to inhibit fungal growth. Lactic acid bacteria were identified as Gram positive, oxidase and catalase negative. The strains isolated were stored at $80{ }^{\circ} \mathrm{C}$ in MRS buffer medium supplemented with $20 \%$ (v/v) glycerol in Eppendorf tubes, for further studies.

Analysis of carbon metabolism of strains isolated: The $L A B$ isolates were analyzed for their ability to produce acid by catabolizing glucose, fructose, sucrose and citrate, which are the main carbohydrates, contained in the cocoa pulp (Afoakwa et al., 2013). The study of sugar metabolism was performed in a modified MRS medium containing the appropriate carbohydrate at $2 \%$ as sole carbon source, $1.7 \%$ agar and supplemented with $0.005 \%$ of bromocresol purple. A volume of $7 \mathrm{~mL}$ of medium was put in a $20 \mathrm{~mL}$ tube and then sterilized for $15 \mathrm{~min}$ at $121^{\circ} \mathrm{C}$. Each strain was cultivated by central sting in the medium and then incubated at $30^{\circ} \mathrm{C}$ for 72 hour in anaerobic conditions. A negative control was prepared in the same conditions and not inoculated with the microbial culture. The capacity of strains to metabolize the carbon source is assessed by the presence of colony in the tube and the change of medium colour due to $\mathrm{pH}$ lowering, comparatively to the negative control.

Evaluation of acidification capacity and fermentative type of LAB: Fermentative type and acidification capacity of bacterial strains was evaluated as previously described by Dicks and Van Vuuren (1987) with slight modification. Each strain was cultivated and incubated as described above, in the same MRS medium. The carbohydrates tested were glucose, fructose and sucrose that are known to be the sugar contained in the cocoa pulp (Afoakwa et al., 2013). Acid production was monitored by formation of yellow area in the tube and acidification capacity was analyzed by evaluating in a visual scale, the spread of the yellow area. The fermentative type was determined by ability of strains to produce gas from carbon source. Indeed, the presence of gas at the bottom of the tube accompanied by yellow zone indicates heterofermentative LAB type.

Evaluation of fermentative capacity of heterofermentative LAB: The quantity of gas produced by heterofermentative $L A B$ is related to the intensity of their carbon metabolism according to the following equation (Raimbiault 1995).
Hence, the fermentative power of heterofermentatives $L A B$ was evaluated by quantifying the gas produced in the medium. A volume of $10 \mathrm{~mL}$ of the MRS medium contained in $20 \mathrm{~mL}$ tubes was seeded with strains and incubated as described above.

Fermentative capacity of strains was estimated by measuring the volume of gas present in the bottom of

\section{RESULT}

Fermentation conditions and bacterial growth: The evolution of fermentation parameters $(\mathrm{pH}$ and the tube after incubation. The volume of gas was determined by the following expression:

$$
V=R^{2} \times \Pi \times h
$$

$V$ : quantity of gas produced in tube, $R$ : ray of tube, $h$ : height occupied by the gas produced

temperature) of the cocoa beans during the process are shown in figure 1. 
A

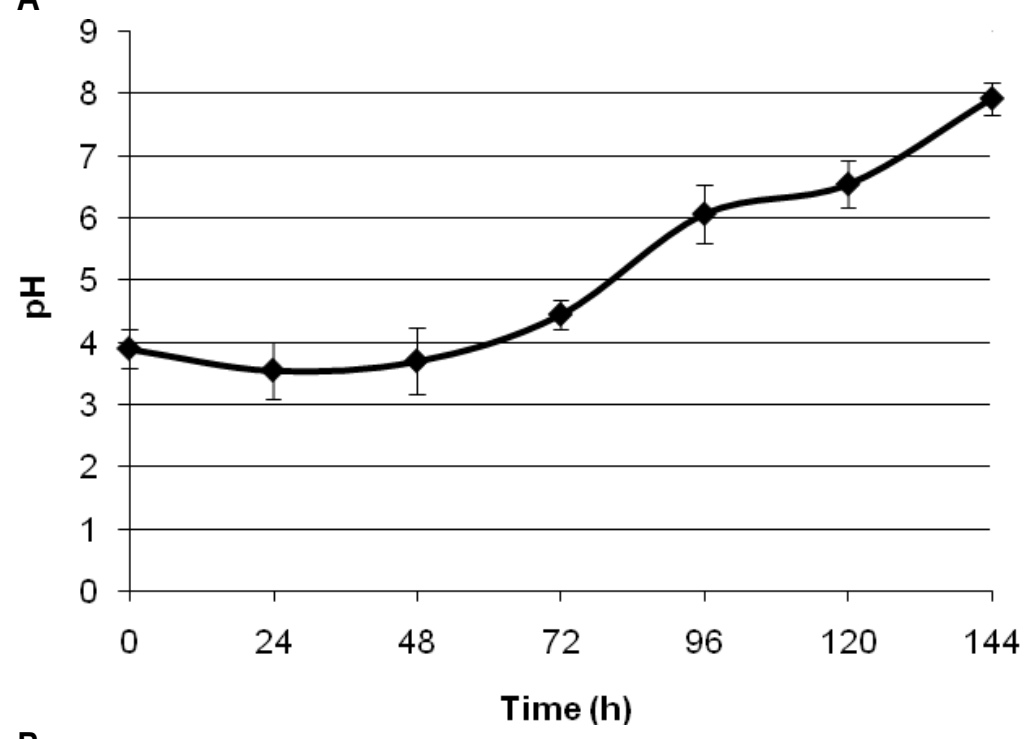

B

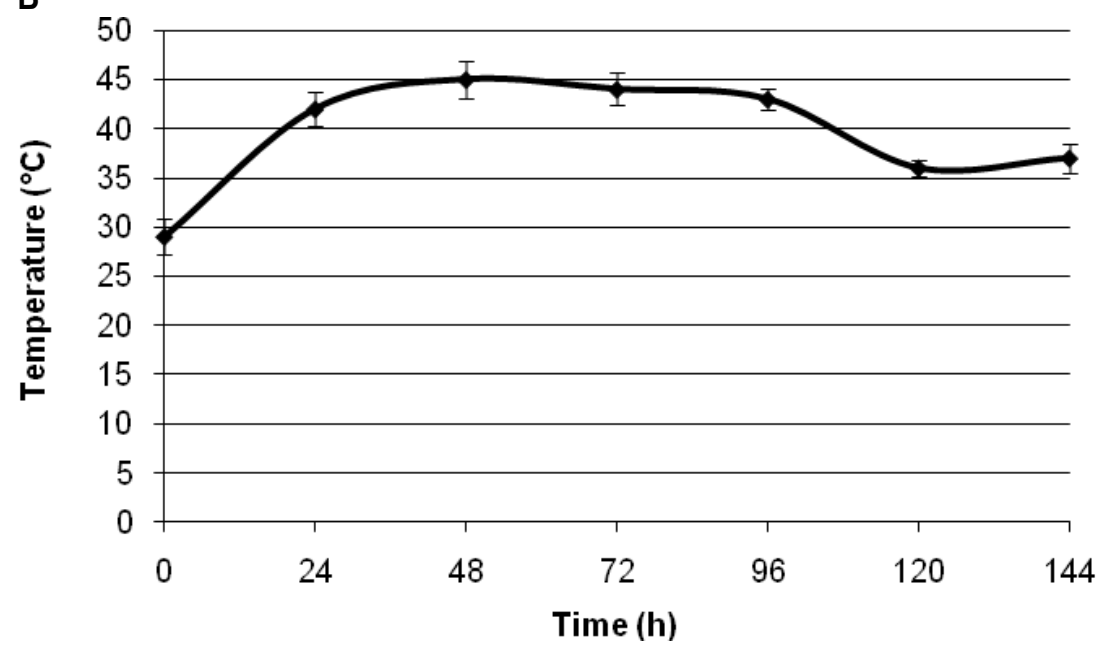

Figure 1: Evolution of pH and temperature during cocoa fermentation. (a) $\mathrm{PH}$, (b) Temperature. Error bars indicate standard deviations between three replicates.

The $\mathrm{pH}$ value inside the cocoa fermenting mass was in the range 3.9-4.45 during the initial stage of the fermentation ( 0 to $48 \mathrm{~h}$ ). After $48 \mathrm{~h}$, the $\mathrm{pH}$ increased to a value of 6.07 at $96 \mathrm{~h}$ and reached a maximum of 7.9 at the end of the fermentative process (Figure 1). Concerning the cocoa bean temperature, the value was $29^{\circ} \mathrm{C}$ at the start of the process and progressively rose to reach a peak of $45^{\circ} \mathrm{C}$ within $48-72 \mathrm{~h}$ (Figure 1). Then the remaining time, a gradual decrease of temperature was observed, dropping at $36{ }^{\circ} \mathrm{C}$ at the end of fermentation. The dynamic of lactic acid bacteria population obtained from numeration during fermentation shows a biphasic mode of growth (Figure 2). The firsts phase concerned a rapid increase of $L A B$ with a change in microbial load from $6.0 \mathrm{log}$ (UFC/g of bean) at the beginning to $7.22 \log$ (UFC/g of bean) at $24 \mathrm{~h}$. This was followed by a decrease of $L A B$ population in the timing 24-48 $\mathrm{h}$. The second phase concerned a slow increase of bacterial growth that reaches a peak of at $96 \mathrm{~h}$ of fermentation. At the end, the process the $L A B$ remained at relatively high load $6.60 \log$ (UFC/g of bean). 


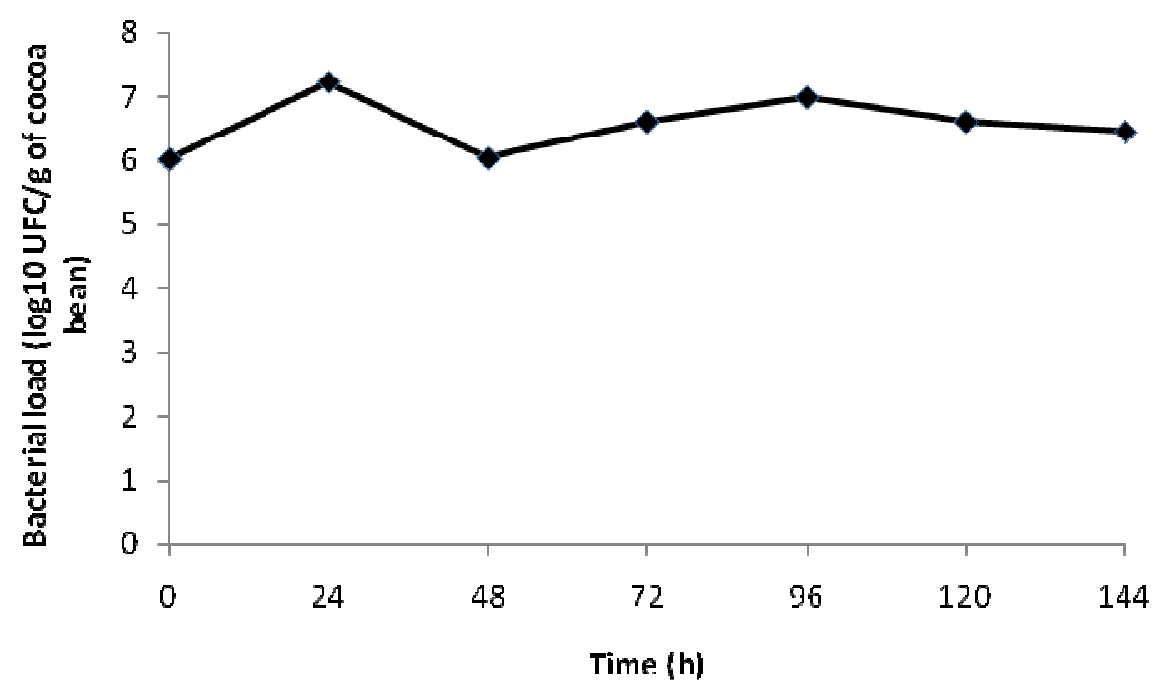

Figure 2: Lactic acid bacteria growth dynamic during cocoa fermentation

Samples of fermenting bean were harvested at $24 \mathrm{~h}$ interval, and microbial numeration was performed by decimal dilution method on MRS, MSE and M17 media as described by Kostinek et al. (2008).

LAB metabolism capacity: A total of 150 LAB strains characterized as Gram positive, oxydase negative, catalase negative and cocci or rods shaped were selected from agar plates of MRS, M17 and MSE during the cocoa bean fermentation process. Among these strains, 99 were lactobacilli and 51 were lactococci. The $L A B$ isolates were screened for their ability to produce acid by catabolizing glucose, fructose, sucrose and citrate. All the strains were naturally able to utilize glucose regarding the change of medium colour due to $\mathrm{pH}$ lowering comparatively to the control. It was also observed that, all the 99 lactobacilli strains were able to ferment fructose and sucrose (Table 1). However, among the 51 lactococci strains, 4 strains were not able to ferment fructose while 6 were unable to metabolize sucrose. In contrast, a wide proportion of LAB was not capable to ferment citrate, only 8 strains all belonging to lactoccoci showed the property to ferment citrate (Table 1).

Table 1: Distribution of lactic acid bacteria (LAB) strains isolates according to the sugar metabolism

\begin{tabular}{ccccccc}
\hline & & & \multicolumn{3}{c}{ Number of LAB metabolizing the sugar } \\
\cline { 2 - 3 } \cline { 5 - 7 } \cline { 5 - 7 } & tested strains & & glucose & fructose & sucrose & citrate \\
Lactobacilli & 99 & & 99 & 99 & 99 & 0 \\
Lactococci & 51 & 51 & 47 & 45 & 8 \\
\hline
\end{tabular}

Strains were grown in modified MRS agar medium containing one of these carbohydrates and incubated for 72 hours at $30^{\circ} \mathrm{C}$.

Acidification capacity: When more acidity is produced, the medium is fully acidified and the yellow zone spread widely in the tube. In contrast, a weak acidification leads to a partial spread of yellow area in the medium. This allowed classifying the strain according to their acidification power (Figure 3). Basing on this principle, strains were classified as fully, moderately or weakly acidifying. All the 150 strains showed naturally, acidification capacity when glucose is use as sole carbon source. Of them, 141 strains proved to be fully acidifying while 8 strains were moderately acidifying and one showed low acidification (Table 2). Moreover, the acidification capacity of strain depended on the sugar metabolized. When fructose is used as sole carbon source, 146 strains presented full acidifying capacity while 4 strains showed an absence of acidification capacity. Additionally, 2 strains among these 146 showed full acidifying capacity with this sugar while they presented a low acid production 
capacity when glucose is use as sole carbon source. The use of sucrose as sole carbon source permit to determine $138 \mathrm{LAB}$ as fully acidifying strains whereas 6 strains presented a low acid production capacity and 5 strains were not able to produce acid with this sugar (Table 2).

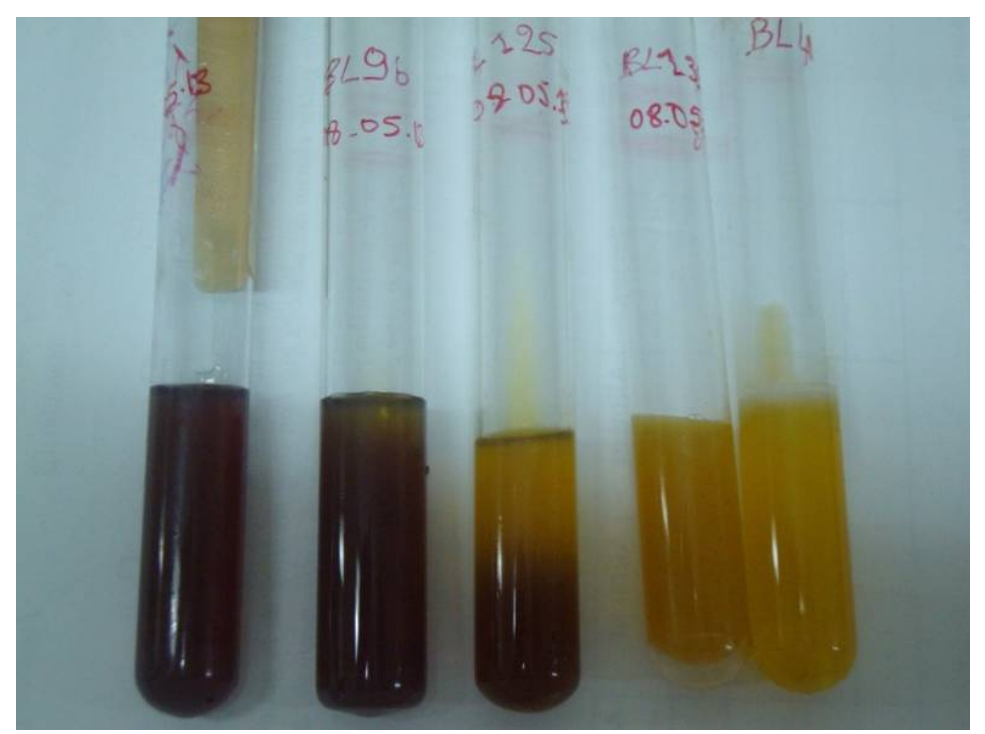

Figure 3: Medium acidified at different levels.

Fully acidified, moderately acidified and weakly acidified. Strains were cultivated in MRS medium by central sting touching the bottom of the tube and incubated for $72 \mathrm{~h}$ at $30^{\circ} \mathrm{C}$.

Table 2: Distribution of lactic acid bacteria ( $L A B)$ strains isolates according to the fermentative type

\begin{tabular}{cccc}
\hline & & Heterofermentatives LAB & Homofermentatives LAB \\
\hline Glucose & Lactococci & 4 & 47 \\
& Lactobacilli & 7 & 92 \\
Fructose & Lactococci & 4 & 44 \\
& Lactobacilli & 6 & 93 \\
& Lactococci & 4 & 46 \\
& Lactobacilli & 4 & 95 \\
\hline
\end{tabular}

LAB group isolates and fermentative capacity: The ability of $L A B$ isolated, to produce gas from glucose metabolism was investigated in order to identify homofermentative and heterofermentative strains. Among the 150 isolates, only $11(7.33 \%)$ were heterofermentatives LAB which produced gas while 124 strains were homofermentatives (Figure 4). Among the heterofermentative LAB, 4 were lactococci and 7 lactobacilli. Additionally, it was observed that some strains producing gas with glucose failed to produce gas with fructose or sucrose. Hence, for a given strain, the same profile regarding gas production was not necessarily observed when the sugar used was different. We further estimated the fermentative power of strains by measuring the volume of gas produced from glucose metabolism. Figure 4 shows that heterofermentative strains produced different volume of gas although they were cultivated in the same conditions. Subsequently, these strains present different fermentative power according to the intensity of metabolism. Similarly, to acidification property, the table 3 shows that gas production also varied with the sugar used for a given strain. For instance, the most important gas producer strain BL 25 produced 2-folds more gas with glucose than with fructose. It appears that glucose offers the most efficient fermentative power with higher gas production in general (Table 3). Furthermore, the best gas producers BL25, BL40 and 
BL08 were also fully acidifying, with the ability to ferment all the sugars studied except citrate and belonged to lactococci. These strains were classified as having a strong fermentative capacity. It was also observed that 2 strains (BL 87 and BL 122) demonstrated the most efficient fermentative power with fructose than glucose and sucrose. We further noted that the 8 strains, which were able to catabolizing citrate, showed a fully acidifying capacity with glucose, fructose and sucrose but without gas production capacity. Moreover, these strains presented a strong fermentative capacity with gas volume ranged $3-4 \mathrm{~mL}$ such as strains BL 08 and BL 40.

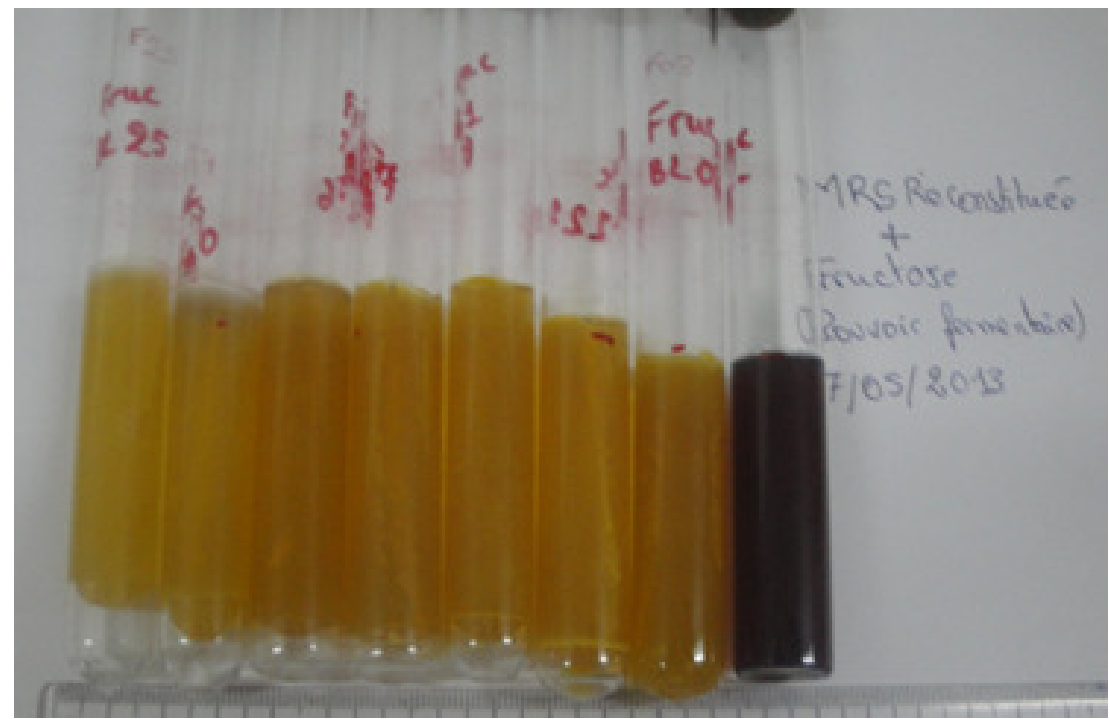

Figure 4: Medium with different volume of gas.

Strong gas production, middle gas production and low gas production. Strains were cultivated in MRS medium by central sting touching the bottom of the tube and incubated for $48 \mathrm{~h}$ at $30^{\circ} \mathrm{C}$.

TABLE 3: Quantity of gas produced by heterofermentative lactic acid bacteria (LAB) strains

\begin{tabular}{lccc}
\hline tested strains & $\begin{array}{c}\text { Gas volume }(\mathrm{mL}) \\
\text { produced with glucose }\end{array}$ & $\begin{array}{c}\text { Gas volume }(\mathrm{mL}) \text { produced } \\
\text { with fructose }\end{array}$ & $\begin{array}{c}\text { Gas volume }(\mathrm{mL}) \text { produced } \\
\text { with sucrose }\end{array}$ \\
\hline BL 07 & $<0.5$ & 0 & 0 \\
BL 08 & 3.534 & $<0.5$ & 2.8272 \\
& & & \\
BL 25 & 5.301 & 2.6505 & 3.534 \\
BL 40 & 3.004 & 2.1204 & 2.6505 \\
BL 55 & 2.1204 & $<0.5$ & 2.4738 \\
BL 56 & 2.297 & 1.414 & 1.0602 \\
BL 61 & 2.474 & 1.5903 & 0 \\
BL 87 & $<0.5$ & 1.5903 & $<0.5$ \\
BL 121 & $<0.5$ & 0 & $<0.5$ \\
BL 122 & $<0.5$ & 1.8835 & 1.2369 \\
BL 139 & 2.1204 & $<0.5$ & 4.7709 \\
\hline
\end{tabular}




\section{DISCUSSION}

The quality of cocoa beans and chocolate depends strongly on the type and characteristics of microbial strains involved in the fermentation. On this basis, the use of starter microbial strains presenting a high fermentative ability is believed to be favourable for cocoa fermentation improvement and producing high quality. In this study, LAB involved in fermentation was analyzed in order to know the properties and the characteristics of $L A B$ involved in Cote d'Ivoire cocoa fermentation. Analysis of heap spontaneous fermentation condition indicates that the $\mathrm{pH}$ of fermentation heap ranged from 3.9 at the beginning to 7.9 at the end of the fermentation process, while the temperature ranged from 29 to $36^{\circ} \mathrm{C}$ with a peak at 45 ${ }^{\circ} \mathrm{C}$ within $48-72 \mathrm{~h}$. The same profile of temperature and $\mathrm{pH}$ variation has been regularly recorded in cocoa fermenting mass in many countries (Schwan and Wheals, 2004, Papalexandratou et al., 2011; Guehi et al., 2010) indicating that the increase of both parameters constitutes an inherent property of cocoa fermentation worldwide. Moreover, $\mathrm{pH}$ continuously increasing during the fermentation became alkaline at the end of the process. Guehi et al. (2010) also reported an alkaline $\mathrm{pH}(8.5)$ at the end of spontaneous cocoa fermentation in Côte d'lvoire. This result is particularly surprising since, it is very often observed that $\mathrm{pH}$ of cocoa fermentation is maximum toward the end, but remains in acidic range (Schwan and Wheals, 2004, Schwan 1998; Guehi et al., 2010). We could not explain the reason for why, sometimes the $\mathrm{pH}$ became alkaline in cocoa fermentation, but this seems to be a particularity of Côte d'Ivoire cocoa fermentation, since alkaline $\mathrm{pH}$ has not been yet reported in other country. On the other hand, the variation of temperature and $\mathrm{pH}$ of cocoa fermenting mass influence the microbial growth (Schwan and Wheals, 2004). The dynamic of lactic acid bacteria population obtained during fermentation shows that $L A B$ are present throughout the fermentative process although a variation in bacterial load was observed, notably the rapid increase of $L A B$ during the first stage and their slow decrease toward the end of fermentation. The same pattern of $L A B$ growth was observed during small scale fermentation in Mexico (Pereira et al., 2012). In contrast, an initial increase of LAB load was followed by a drastic decrease from $80 \mathrm{~h}$ until the microorganisms were not detectable during spontaneous wooden box cocoa fermentation in Brazil (Schwan 1998). Hence, fermentation may sometime imply stress conditions susceptible to limit the microbial growth and subsequently to counterbalance their favourable technological properties. Regarding their growth kinetic during fermentation, the results suggest that $L A B$ studied should be competitive and capable to survive under certain stress conditions and eventually to express their fermentative potential during the fermentation process. Biochemical and morphological identification of strains isolated, revealed as expected the presence of Lactococci (34 \%) and Lactobacilli (66 $\%)$ in Ivorian spontaneous cocoa fermentation. Lactobacilli were also found to be dominant in Ghanaian and Nigerian cocoa fermentation (Camu et al., 2007; Kostinek et al., 2008). At date, the possible impact of the balance between both types of $L A B$, on the quality of bean is not elucidated. However, the results also showed that homofermentative strains are widely dominant among the $L A B$ isolated as it is reported in Ghana (Camu et al., 2007) and Nigeria (Kostinek et al., 2008). Homofermentative LAB strains are known to convert sugars almost exclusively into lactic acid and then produce more lactic acid than heterofermentative strains (Raimbiault 1995). Although acid production during cocoa fermentation is desirable for development of precursors chocolate aroma (Biehl et al., 1993; Jinap 1994), a high production of less volatile lactic acid is liable to confer to fermented and dried beans a final acidity that deteriorate their quality (Schwan and Wheals, 2004). To this point of view heterofermentative strains producing other acid more volatile such as acetic acid, may be more interesting and desirable, but this type of strain remains in minor proportions in spontaneous cocoa fermentation as also showed by our results. Heterofermentative metabolism is characterized by gas (carbon dioxide) and acid other than lactic acid production (Raimbiault 1995). This study showed different level of gas production from sugar metabolism suggesting different fermentative power. Strains producing more gas were also observed to be fully acidifying suggesting that both properties are linked. The acidification of bean, allow activation of hydrolytic enzymes deep into the cotyledons (Jinap 1994); these enzymes notably aspartic endoprotease and serine carboxypeptidase catalysis the production of precursor of chocolate flavour from globular proteins (Biehl et al., 1993; Voigt et al., 1994; Serra and Ventura, 1997) while gas production reflect the fermentative power, and then the ability of strain to speed the fermentation. One the other hand, some 
homofermentative LAB isolates all belonging to lactococci presented the capacity to catabolizing citric acid. These results are consistent with the observation according to which lactococci are more susceptible to catabolize citrate than lactobacilli (Drinan et al., 1976). It was also reported that in experimental conditions, homofermentative lactococci produce more acetoin and diacetyl amount from citrate degradation than heterofermentative Lactobacilli (Drinan et al., 1976). Furthermore, citrate metabolism constitutes, an important and particular property, since $L A B$ is not usually able to utilize citric acid as carbon source. To our knowledge, no report exists on bacterial strain from cocoa fermentation metabolizing citrate as carbon source. Citric acid is the compound responsible for the initial pH of cocoa pulp before fermentation processing (Pettipher 1986; Thompson et al., 2001; Ardhana and Fleet, 2003, Lefeber et al., 2011). The degradation of this acid in the first stage of fermentation allows the raise of the $\mathrm{pH}$ favourable for the development of many

\section{REFERENCES}

Adams MR, 1998. Vinegar. In: Wood, Brian, J.B. (Ed.), Microbiology of Fermented Foods. Blacki Academic and Professional, London, pp. 1-44.

Adeyeye El, Akinyeye RO, Ogunlade I, Olaofe O, Boluwade JO, 2010. Effect of farm and industrial processing on the amino acid profile of cocoa beans. Food Chem. 118:357-363.

Afoakwa EO, Kongor JE, Takrama JF, Budu AS, 2013. Changes in acidification, sugars and mineral composition of cocoa pulp during fermentation of pulp pre-conditioned cocoa (Theobroma cacao) beans. International Food Research Journal 20 (3): 1215-1222.

Ardhana M, and Fleet G, 2003. The microbial ecology of cocoa bean fermentations in Indonesia. International Journal of Food Microbiology 86:87-99.

Barel M, 1996. La Fermentation de Cacao, in "Microbiologie Alimentaire" Tome 2 C.M. Bourgeois, J-P. Larpent, Coordonnateurs Tec et Doc Lavoisier.

Biehl B, Voigt J, Heinrichs H, Senjuk V, Bytof G, 1993. $\mathrm{pH}$-dependent enzymatic formation of oligopeptides and amino acids, the aroma precursors in raw cocoa beans. In: Lafforest, J. (Ed.), Proceedings in XIth International Cocoa Research Conference. Cocoa Producers' bacterial groups (Schwan and wheals, 2004). Accordingly, possessing citrate metabolism constitutes a valuable trait for cocoa fermentation, since this could allow enhancing microbial metabolism, strengthening fermentation and subsequently have a possible contribution to cocoa and chocolate quality.

In conclusion, LAB flora studied were composed of lactobacilli and lactococci, presenting either homofermentative or heterofermentative metabolism. These bacteria were able to grow throughout the fermentation with capacity to metabolize glucose, fructose and sucrose. Furthermore, some homofermentative lactococci strains presented the capacity to metabolize citrate as carbon source, a valuable property for cocoa fermentation. All together, these results show that strains behave differently and indicate that some of them present interesting technological traits potentially useful for their utilization as starters in cocoa fermentation.

Alliance, Yamassoukro, Ivory Coast, pp. 717722.

Camu N, DeWinter T, Addo SK, Takrama JS, Bernaert H, De Vuyst L, 2008a. Fermentation cocoa beans: influence of microbial and polyphenol concentrations on the flavour of chocolate. Journal of Science of Food and Agriculture 88: 2288-2297.

Camu N, González Á, De Winter T, Van Schoor A, De Bruyne K, Vandamme P, Takrama JS, Addo SK, De Vuyst L, 2008b. Influence of turning and environmental contamination on the dynamics of populations of lactic acid and acetic acid bacteria involved in spontaneous cocoa bean heap fermentation in Ghana. Applied and Environmental Microbiology. 74: $86 \mathrm{e} 98$.

Camu N, De Winter T, Verbrugghe K, Cleenwerck I, Vandamme P, Takrama JS, Vancanneyt M, De Vuyst L, 2007. Dynamics and Biodiversity of Populations of Lactic Acid Bacteria and Acetic Acid Bacteria Involved in Spontaneous Heap Fermentation of Cocoa Beans in Ghana. Applied and Environmental Microbiology, p. 1809-1824.

Carr JG, Davies PA, 1980. Cocoa Fermentation in Ghana and Malaysia: Further Microbial Methods and Results. Bristol. University of 
Bristol Research Station, Long Ashton, Bristol and Tropical Products Institute, Gray's Inn Road, London.

De Roissart $\mathrm{H}$ and Luquet FM, 1994. Les bactéries lactiques. Uriage, Lorica, France, vol. 1. pp. 1286

Dicks LM and Van Vuuren HJJ, 1987. Microbiology Methods, 6: 273-275.

Drinan DF, Tobin S, Cogan TM, 1976. Citric Acid Metabolism in Hetero- and Homofermentative Lactic Acid Bacteria. Applied and Environmental Microbiology, p. 481-486.

Guehi ST, Soumaila D, Ban-Koffi L, Kra DK and Zahouli GIB, 2010. Effect of Turning Beans and Fermentation Method on the Acidity and Physical Quality of Raw Cocoa Beans. Adv. J. of Food Sci. and Technol. 2(3): 163-171.

Hansen CE, del Olmo M, Burri C, 1998. Enzyme activities in cocoa beans during fermentation. J. Sci. Food Agric. 77: 273-281.

Hashim P, Selamat J, Muhammad SKS, Ali A, 1998. Changes in free amino acid, peptide-N, sugar and pyrazine concentration during cocoa fermentation. J. Sci. Food Agric. 78:535-542.

Hii CL, Law CL, Cloke M, Suzannah S, 2009. Thin layer drying kinetics of cocoa and dried product quality. Biosyst. Eng., 102: 153-161.

Jespersen L, Nielsen DS, Hønholt S, Jakobsen M, 2005. Occurrence and diversity of yeasts involved in fermentation of West African cocoa beans. FEMS Yeast Research 5: 441-453.

Jinap S, 1994. Organic acids in cocoa beans - a review. ASEAN Food J. 9: 3-12.

Koen I, De Vuyst L, Papalexandratou Z, Weckx S, 2012. Phylogenetic analysis of a spontaneous cocoa bean fermentation metagenome reveals new insights into its bacterial and fungal community diversity. Plos one 7: e38040.

Kostinek M, Ban-Koffi L, Ottah-Atikpo M, Teniola D, Schillinger U, Holzapfel WH, Franz CMAP, 2008. Diversity of Predominant Lactic Acid Bacteria Associated with

Cocoa Fermentation in Nigeria. Curr Microbiol, 56:306314.

Lefeber T, Janssens M, Moens F, Gobert W, De Vuyst $L$, 2011. Interesting starter culture strains for controlled cocoa bean fermentation revealed by simulated cocoa pulp fermentations of cocoa-specific lactic acid bacteria. Applied and Environmental Microbiology 77: 6694-6698.
Lehrian D W and Patterson G R, 1983. Cocoa fermentation, p. 529-575. In G. Reed (ed.), Biotechnology, a comprehensive treatise, vol. 5. Verlag Chemie, Basel, Switzerland.

Moreira I M da Veiga, Miguel MG da Cruz P, Duarte WF, Dias DR, Schwan RF, 2013. Microbial succession and the dynamics of metabolites and sugars during the fermentation of three different cocoa (Theobroma cacao L.) hybrids. Food Research International 54: 9-17.

Nielsen DS, Teniola OD, Ban-Koffi L, Owusu M, Andersson T and Holzapfel W H, 2006. The microbiology of Ghanaian cocoa fermentations analysed using culture dependent and culture independent methods. International Journal of Food Microbiology. Accepted for publication.

Nielsen PS, 2006. Determination of the degree of cocoa fermentation using spectroscopy and multivariate data analysis. Master Thesis, Department of Food Science, The Royal Veterinary and Agricultural University, Denmark.

Nielsen DS, Honholt S, Tano-Debrah K, and Jespersen L, 2005. Yeast populations associated with Ghanaian cocoa fermentations analysed using denaturing gradient gel electrophoresis (DGGE). Yeast 22:271-284.

Nielsen DS, Teniola OD, Ban-Koffi L, Owusu M, Anderson TS, Holzapfel WH, Vancanneyt M, and De Vuyst L, 2007. Dynamics and biodiversity of populations of lactic acid bacteria and acetic acid bacteria involved in spontaneous heap fermentation of cocoa beans in Ghana. Appl. Environ. Microbiol. 73:1809-1824.

Ouattara HG, Ban-Koffi L, Karou GT, Sangare A, Niamke SL, Diopoh JK, 2008. Implication of Bacillus sp. in the production of pectinolytic enzymes during cocoa fermentation. World J. Microbiol. Biotechnol. 24: 1753-1760.

Papalexandratou Z, Vranckena G, De Bruyne K, Vandamme P, De Vuyst L, 2011 Spontaneous organic cocoa bean box fermentations in Brazil are characterized by a restricted species diversity of lactic acid bacteria and acetic acid bacteria. Food Microbiol 28: 1326-1338.

Passos FML, Silva DO, Lopez A, Ferreira CLLF, Guimaraes WV, 1984. Characterization and distribution of lactic acid bacteria from 
traditional cocoa bean fermentations in Bahia. J. Food Sci. 49: 205-208.

Payne MJ, Hurst WJ, Miller KB, Rank C, Stuart DA, 2010. Impact of fermentation, drying, roasting, and Dutch processing on epicatechin and catechin content of cacao beans and cocoa ingredients. J. Agric.

Pereira GV de Melo, Miguel MG da Cruz P, Ramos CL, Schwan RF, 2012. Microbiological and physicochemical Characterization of SmallScale Cocoa Fermentations and Screening of Yeast and Bacterial Strains to Develop a Defined Starter Culture. Applied and Environmental Microbiology p. 5395-5405.

Pettipher GL, 1986. Analysis of cocoa pulp and the formulation of a standardized artificial cocoa pulp medium. Journal of the Science of Food and Agriculture 37: 297-309.

Raimbiault M, 1995. Importance des bactéries lactiques dans les fermentations du manioc. In Transformation Alimentaire du Manioc. T.
Agbor Egbe, A. Brauman, D. Griffon, S. Trèche (éd ORSTOM).

Schwan RF and Wheals AE, 2004. The microbiology of cocoa fermentation and its role in chocolate quality. Crit Rev Food Sci Nutr 44: 205-221.

Schwan RF, 1998. Cocoa fermentation conducted with a defined microbial cocktail inoculum. Appl. Environ. Microbiol. 64: 1477-1483

Serra BJ and Ventura CF, 1997. Evaluation of bitterness and astringency of polyphenolic compounds in cocoa powder. Food Chem. 60: 365-370.

Thompson SS, Miller KB, Lopez AS, 2001. Cocoa and coffee. Food Microbiology-Fundamentals and Frontiers. 35 (2): 721-733.

Voigt J, Biehl B, Heinrich H, Kamaruddin S, Gaim Marsoner G, Hugi A, 1994. In vitro formation of cocoa specific aroma precursors: Aromarelated peptides generated from cocoa seed protein by cooperation of an aspartic endoprotéase and a carboxypeptidase. Food Chem. 49: 173-180. 